\title{
Morphological description of Cyrtopleura costata (Bivalvia: Pholadidae) from southern Brazil
}

\author{
Nicole Stakowian' \& Luiz Ricardo L. Simone ${ }^{2}$ \\ 1 Universidade Federal do Paraná (UFPR), Setor de Ciências Biológicas, Departamento de Zoologia (DZO0), Programa de Pós-Graduação em Zoologia. \\ Curitiba, PR, Brasil. ORCID: http://orcid.org/0000-0002-3031-783X. E-mail: nicolestakowian@outlook.com \\ ${ }^{2}$ Universidade de São Paulo (USP), Museu de Zoologia (MZUSP). São Paulo, SP, Brasil. \\ ORCID: http://orcid.org/0000-0002-1397-9823. E-mail: Irsimone@usp.br
}

\begin{abstract}
The aim of the study is to describe in detail, for the first time, the internal and external anatomy of Cyrtopleura costata, which displays ellipsoid and elongated valves with beige periostracum, the anterior adductor muscle unites the valves in the preumbonal region, with abduction capacity in its dorsal half, sparing the ligament. Two accessory valves are identified: the mesoplax (calcified) located in the umbonal region; and the protoplax (corneus) above the anterior adductor muscle. Internally there is a pair of well-developed apophysis that supports the labial palps and the pedal muscles, and support part of the gills. The posterior half of mantle ventral edge is fused and richly muscular, working as auxiliary adductor muscle. The siphons are completely united with each other, the incurrent being larger than the excurrent. The foot is small (about $1 / 8$ the size of the animal). The kidneys extend laterally on the dorsal surface, solid, presenting a brown/reddish color. The style sac is well developed and entirely detached from the adjacent intestine. The intestine has numerous loops and curves within the visceral mass. The fecal pellets are coin-shaped. The present study certainly may be used as comparative scenario for specimens from other regions of the species range.
\end{abstract}

Keywords. Taxonomy; Bivalve; Morphology; Myida; Pholadoidea.

\section{INTRODUCTION}

The bivalves are the second largest class of the phylum Mollusca in diversity and, accordingly, of high economic and ecological importance (Bieler \& Mikkelsen, 2006; Bieler et al., 2013; Gomes-dosSantos et al., 2019). Bivalves constitute an ideal group to answer biological questions around morphological adaptations to dig, drill, swim and attach on several substrates (Bieler, 2006; Bieler et al., 2013).

Although the available knowledge about bivalves is relatively extensive and dates back to several centuries, there are still many gaps to be filled. Moreover, many species are still to be described and identified, as well as the current known species must be better defined (Bieler et al., 2013). The magnitude of megadiverse groups, such as Mollusca, hampers large-scale research, and in classical morphological studies, it is usual a functional single organ anatomy characterization. In this framework, morphological generalizations for other groups and specimens are common. In addition, there are scant attention to soft parts anatomy, with studies focusing only on description of the shell, although the taxonomic importance of the internal organs.
Pholadidae Lamarck, 1809 is a family of burrowing bivalves present into different hard and soft ground substrates, such as clay, limestone, rocks and mud (Turner, 1954). Several species have shown economic importance as an important source of protein (Ribas, 2014) in Europe (Arias \& Richter, 2012) and in the Philippines (Bin Ramli \& Yusop, 2016). The group has a set of features that reflects the punch/burrowing habit, such as accessory valves, apophyses, the presence of spines along the valves surface, hinge ligament reduction (or loss) and anterior adductor muscle entered dorsally, which allows the valves to move on a dorsoventral axis. This arrangement is exclusive of the pholadid bivalves (Ansell \& Nair, 1969; Ito, 2005; Monari, 2009; Jeon et al., 2012).

Cyrtopleura costata (Linnaeus, 1758) is a burrowing pholadid, inhabitant of the infauna of muddy regions of the intertidal from the east coast of Canada to southern Brazil (Rios, 2009; Velásquez, 2017; Cullain et al., 2018). The Cyrtopleura galleries have a narrow opening and an internal chamber that contributes to increased complexity of the ecosystem, acting as ecosystem engineers (Pinn et al., 2005; Haider et al., 2018). Despite being one of the most conspicuous species of Pholadidae, with easily recognizable large individuals (Turner, 1954), little is known about its anatomy, except 
for the macroscopic descriptions and brief note in basic anatomy (Dall, 1889; Turner, 1954) and the ciliary focused study of Kellogg (1915).

Studies of descriptive morphology can provide new characters for phylogenetic studies, contributing towards the description of new species and for the survey of local biodiversity, besides serving as the basis for further researches. Studies describing soft anatomy are scattered for Pholadidae, with few examples (Dall, 1889; Turner, 1954; Purchon, 1955; Morton, 1973; Wong, 1982; Turner \& Santhakumaran, 1989). Thus, this study aimed to describe the shell and soft parts morphology of $C$. costata specimens from a population located in southern Brazil, Paranaguá Bay, Paraná. The intention is, in the future, to compare with other populations from the extraordinary wide geographic range of the species.

\section{MATERIAL AND METHODS}

The specimens were collected in the Paranaguá Bay (State of Paraná, Southern Brazil) $\left(25^{\circ} 43^{\prime} 53,17^{\prime \prime} \mathrm{S}\right.$, $\left.48^{\circ} 44^{\prime} 63,05^{\prime \prime} \mathrm{W}\right)$, then shortly relaxed in menthol for 30 minutes, and fixed in formalin $10 \%$ for at least 24 hours, with posterior conservation in ethanol $70 \%$. Dissection was performed using standard techniques under stereomicroscope (Simone et al., 2015), with animals immersed in alcohol. Internal structures were observed by removing the integument from the visceral mass and scraping the gonadal tissue. Transverse sections of the labial palp were submitted to histological procedures (adapted from Borzone et al., 2001). The drawings were done with the aid of a camera lucida. Additional conchological material from other sites was examined and termed just "shell". The collected and dissected bivalves are treated as "specimens". The material examined is in the results.

Abbreviations in the figures: aa, auxiliary adductor muscle; am, anterior adductor muscle; an, anus; ao, aorta; ap, apophyses; au, auricle; bv, "blood" vessel; cc, cerebrovisceral connective; cg, cerebropleural ganglia; $\mathrm{cv}$, ctenidial (efferent) vessel; dg, digestive gland; es, esophagus; esp, excurrent siphon; fg, food grooves; fvm, flap of visceral mass; fm, fusion between left and right mantle lobes; ft, foot; go, gonad; gp, gonóporo; ic, inner ciliary connection of gill; id, inner demibranch; idm, insertion of outer demibranch in mantle; in, intestine; ip, inner hemipalp; is, incurrent siphon; it, inner tentacle; ki, kidney; mb, mantle border; me, mantle; mi, mantle border inner fold; $\mathrm{mm}$, mantle border middle fold; mo, mantle border outer fold; mt, metaplax; $\mathrm{np}$, nefróporo; oc, outer tissue connection of gill; od, outer demibranch; op, outer hemipalp; ot, outer tentacle; pc, pericardium; pm, posterior adductor muscle; pn, pallial nerve; pp, labial palp; pr, pericardial region; pt, protoplax; rm, radial siphonal muscle; rt, rectum; sb, suprabranchial chamber; sc, sockets; sg, selection groove; sh, shell; sm, siphonal retractor muscle; sn, siphonal nerve; sp, siphon; ss, style sac; ss-st, conjoined style sac-stomach; st, stomach; st-in, conjoined style stomach-intestine; un, union between the mantle lobes; ve, ventricle; vg, visceral ganglia.

\section{RESULTS}

\section{Cyrtopleura costata (Linnaeus, 1758)}

(Figs. 1-2)

Pholas costatus: Linnaeus, 1758: 669; Lamarck, 1818: 445; 1835: 45; Tryon, 1862: 201; Schepman, 1887: 156, 164. Capulus shreevei: Conrad, 1869: 105, pl. 13, fig. 3.

Scobina costata: Bayle, 1880: 242.

Pholas (Barnea) costatus: Linnaeus, 1759 (sic): Grant \& Gale, 1931: 431.

Cyrtopleura (Scobinopholas) costata: Turner, 1954: 35, pls. 17-18; Altena, 1968: 156, 176; 1971: 78, pl. 6, figs. 10-11; Pacaud, 1998: 64-65, figs. 21-22.

Cyrtopleura costata: Perry \& Schwengel, 1956: 94, pl. 19, fig. 124; Moore, 1961: 49; Turgeon, 1968: 71, fig. 43; Hoagland, 1983: 44; Spencer \& Campbell, 1987: 54, pl. 9, figs. 19-20.

Material examined: EUA. Florida, Pierce, Bathtub Beach, MZSP 46850, 1 shell. BRAZIL. Bahia, Ilhéus, Olivença, MZSP 101530, 1 shell; Rio de Janeiro, Ibicuí, Almirante Aratanha, MZSP 144243, 1 shell; São Paulo, Iguape, MZSP 20106, 1 shell; Paraná, Baía de Paranaguá, Comunidade de São Miguel, MZSP 143461, 8 specimens.

Distribution: From eastern Canada, USA, México, Cuba, and South America, from Venezuela to southern Brazil (Rios, 2009; Velásquez, 2017; Cullain et al., 2018).

Habitat: sandy to silt-muddy bottom $40 \mathrm{~cm}$ depth.

\section{Description}

Shell (Fig. 1A-E, G, H): Opaque beige to white, thin, with radial ornamentation extending from umbo region to ventral edge; more protruded (perceptible) in anterior and posterior regions (Figs. 1A, C, E). Shape ellipsoid and elongated with anterior and posterior margin rounded (Figs. 1A, B). Posterior region narrowing gradually, extending posteriorly to base of siphonal process (Figs. 1C, D). Anterior edge of valves reflected, anterior to umbo (Fig. 1H); insertion of anterior adductor muscle upwards, external to valves (Figs. 1D: am). Sockets formed below and posteriorly to reflection (Fig. $1 \mathrm{H}$ : sc), where mantle flaps (Fig. 2l) are inserted. Periostracum brown, translucent, well-developed near edges (Fig. 1D: pr). Pallial line apparent, pallial sinus wide and shallow $(\sim 1 / 3$ valve length) (Fig. 1B). Apophysis with same thickness of valves, long ( half valve width) and wide spoon-shaped (Fig. 1B: ap). Posterior adductor muscle scar smaller than anterior, close to dorsal edge. Two accessory plates: protoplax chitinous and large, anterior to umbo covering anterior adductor muscle (Figs. 1A: pt; 1G: pt); mesoplax calcareous, located posterior to umbo, below anterior adductor (Figs. 1A: mt; 1G: mt). Ligament absent.

Main muscle system (Figs. 2A, B, E): Proportions and location of adductor muscles recognizable by shell in- 
ternal scars as described above. Paired anterior pedal retractor muscles originates into outer edge of apophysis. Fusion of ventro-posterior edge of pallial edge thick muscular, mostly with transverse muscles, possibly working as auxiliary adductor muscle (Fig. 2A: aa). Siphonal retractor muscle arranged in bundles and well-demarcated on mantle surface; origin like fan in siphonal base (Fig. 2A: sm). Anterior and posterior re- tractor muscles of foot not individualizable, both pairs present as thickening region of integument surrounding adductor muscles. No clear protractor muscles detected.

Foot (Figs. 1C, E; 2B): relatively small ( 1/8 of animal's size) (Fig. 1E: ft) origin in visceral mass slightly superficial (explained in Discussion).

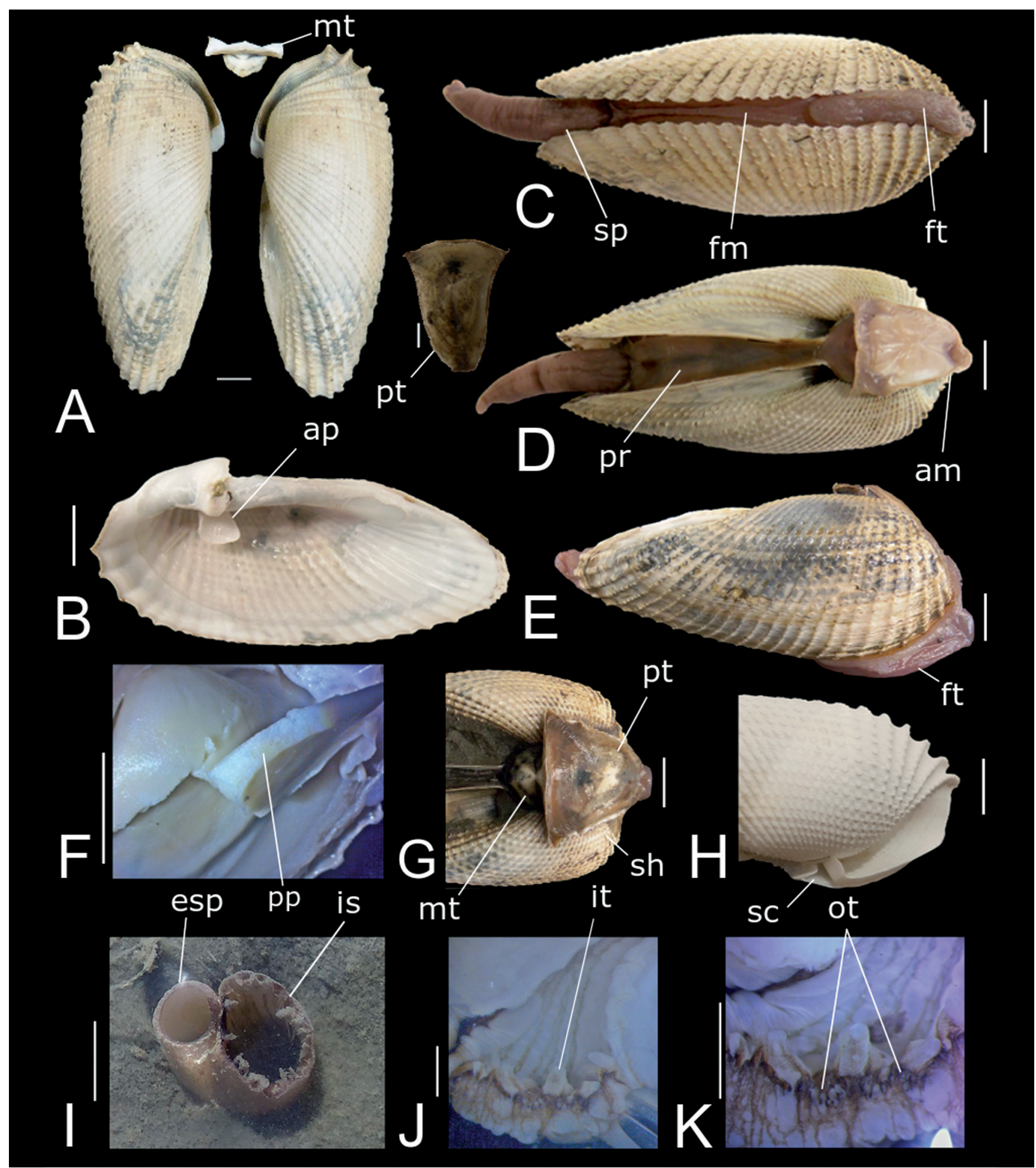

Figure 1. Shell and anatomic aspects of Cyrtopleura costata (MZSP 143461): (A) valves and accessory plates, external view; (B) left valve, internal view; (C) ventral whole view; (D) dorsal whole view; (E) left whole view; (F) left outer hemipalp cross section; (G) detail of location of accessory plates, anterior region, dorsal view; (H) left valve showing where flaps of mantle are inserted in region just posterior to umbo; (I) siphon in situ opening out of gallery; (J) incurrent siphon tip, opened longitudinally; $(K)$ incurrent siphon margin detail. Scale bar: $A-I=1 \mathrm{~cm} ; J, K=1 \mathrm{~mm}$. 
Mantle: Edges mostly fused, through inner fold (Fig. 2J). Siphons completely merged with each other; base surrounded by, but not connected to, periostracum layer. Incurrent siphon with around twice diameter of excurrent one (Fig. 1I), with folded edge on itself (Fig. 1J: it), bearing larger tentacles arranged on internal edge and smaller ones situated on outer edge. (Fig. 1K: ot); internal longitudinal folds present. Excurrent siphon smooth, with tiny tentacles just on margin. Both siphons possessing brownish-red pigmentation, reaching $\sim 3$ times

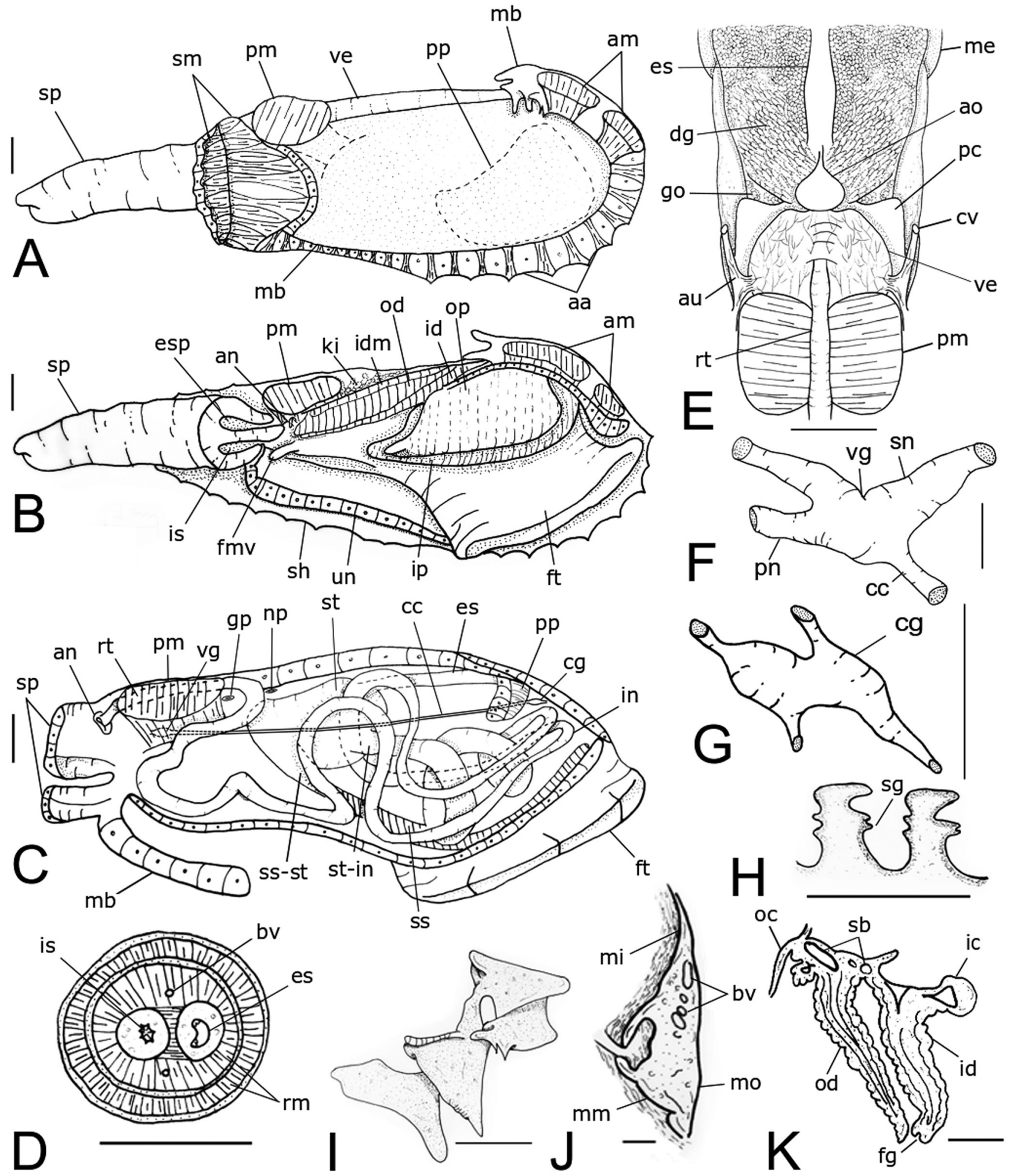

Figure 2. Cyrtopleura costata general anatomy: (A) whole right view shell removed; (B) pallial cavity whole, fusion of both mantle lobes sectioned longitudinally, right mantle lobe removed; (C) digestive system in situ, right view, topologies of some adjacent structures also shown; (D) siphons, transverse section in their middle level; (E) pericardial region, dorsal view; (F) visceral ganglia lateral view; (G) cerebropleural ganglia lateral view; (H) labial palp profile in cross section; (I) flaps of mantle in region just posterior to umbo, right view; (J) transverse section of right mantle edge; (K) gill, cross section at mid-region. Scale bar: $A-C, E, I=1 \mathrm{~cm}$; $D, J, K=2 m m ; F, G=1 \mathrm{~mm} ; \mathrm{H}=200 \mu \mathrm{m}$. 
or longer than valves' length. Pedal gap slightly smaller than half of ventral mantle edge (Fig. 1C).

Pallial cavity (Fig. 2B): Labial palps very thick occupying $\sim 1 / 3$ of pallial area (Figs. 1F; 2B: op, ip) located inside umbonal cavity. Hemipalps triangular and asymmetrical; outer hemipalp slightly smaller than inner one, both with posterior distal tip. Angle between ridges remaining same in basal and distal halves, with largest (widest) selection grooves located at upper end of ridges and smallest (narrowest) located just below (Fig. 2H). Inner demibranch passing between hemipalps but not fused to them - Stasek's category I (Stasek, 1963), larger than outer demibranch, and with ciliary connection with visceral mass (Fig. 2B: id, od). Outer demibranch, showing no contact with labial palps, displaying tissue connection with visceral mass along base of ctenidial axis (Fig. 2J). Both dorsal-ventrally short, around half of pallial cavity in length, gradually becoming wider towards posterior region.

Visceral mass (Fig. 2C): Stomach located ventrally at mid region (Fig. 2C: st). Intestinal looping starts at exit of stomach (anteroventral region) in form of spiral, then making a return and ascending movement towards esophagus, passing behind (right side) stomach and returning forming a second intestinal loop parallel to previous one. It also rises towards esophagus (more posteriorly compared to first), further passing through front of stomach (left side), then travels through ventral region of visceral mass to base of siphons, returning behind posterodorsal region of stomach, crossing pericardium, ending with anus, located at base of exhaling siphon (Fig. 2C). Gonad fulfilling entire remaining visceral space.

Circulatory and excretory systems (Fig. 2B, C, E): Pericardium compressed dorsally; just anterior to posterior adductor muscle (Fig. 2E: pc). Auricles with rose tone, walls very thin (Fig. 2E: au). Ventricle large (Fig. 2E: ve), rectum passing through center of it (Fig. 2E: rt). Kidney underdeveloped, spongy, solid; extending laterally on dorsal surface, color reddish-brown (Fig. 2B: ki). Nephropore located near base of excurrent siphon (Fig. 2C: np).

Digestive system (Fig. 2C): Labial palp described above. Mouth close to anteroventral surface of anterior adductor muscle. Esophagus narrow, attached to adductor at intersection of labial palps, running horizontally along dorsal visceral mass, inserting in anterodorsal side of stomach (Fig. 2C: es). Inner stomach surface not observed. Digestive gland lying on each side. Style sac well-developed, apart from intestine; extending until anterior end of visceral mass; almost as long as visceral sac (Fig. 2C: ss). Intestinal origin large, located in anteroventral region. Intestine relatively narrow, with numerous loops as described above, becoming gradually thinner towards posterior. Fecal pellets stacked up, coin-shaped along posterior portion of intestine.

Reproductive system: Gonad described above. Genital duct not detected. Genital pore located close excurrent siphon, anterior to anus, under and slightly posterior to nephropore (Fig. 2C: gp).

Nervous system (Fig. 2C, F, G): Pedal ganglia remained undetected. Cerebropleural ganglia located under insertion of anterior adductor (Figs. 2C: cg; 2G). Visceral ganglia located on anteroventral side of posterior adductor muscle (Figs. 2C: vg; 2F). Cerebrovisceral connectors crossing visceral mass (Figs. 2C: cc; 2F: $\mathrm{cc}$ ).

\section{DISCUSSION}

Cyrtopleura costata has the typical Pholadidae radially crimped shaped valves, which may vary due to age, population size and sort of substrate (Turner, 1954; Purchon, 1955; Wong, 1982). Like other representatives of the family, C. costata has sculpture on the surface of the valves that are adapted to substrate abrasion and indicate a preference for a particular type of substrate, as well as phylogenetic relationships (Ito, 2005). Only one individual had pink coloration in the umbonal region and on the anterior adductor muscle. This seems to be more common in certain populations, such as those from the west coast of Florida (Turner, 1954). About the accessory valves, the mesoplax is chitinous, which may be due to the low abrasion suffered by the valves within of the burrowed sediment (Morton, 1973; Turner \& Santhakumaran, 1989; Fiori et al., 2012; Voight \& Segonzac, 2012).

Burrowing pholadids are known to have an apophysis that protrudes from the umbonal region toward the visceral mass. Pholadids like Barnea parva (Pennant, 1777), B. candida (Linnaeus, 1758), Pholas dactylus Linnaeus, 1758, Pholadidea loscombiana Turton, 1819, Zirfaea crispata (Linnaeus, 1758) and Z. subconstricta (Yokoyama, 1924), have apophysis as a support for the insertion of the pedal muscles (Purchon, 1955; Ito, 2005). Despite C. costata is not burrowing in the adult phase (Gustafson et al., 1991), it has a well-developed apophysis that supports the labial palps, the pedal muscles, the gills, and, provably, the visceral mass, through its robustness and wide spoon-shaped surface.

A ligament was not observed in C. costata, as seems to be common for Pholadidae, as in B. candida, $P$. dactylus and P. loscombiana (Purchon, 1955). It is suggested that the degree of reduction or loss of the ligament is related to the rate of boring activity - highly burrowing pholadids do not have ligament. Purchon (1955) argued that the ligament reduction allows valves to move along a vertical axis facilitating the burrower action on harder substrates. In this way, the articulation of the valves is related to the modified anterior adductor muscle, positioned dorsal and externally, which takes the position of the ligament, allowing a diductor movement of the valves (Wong, 1982; Savazzi, 1987; Turner \& Santhakumaran, 1989; Ito, 2005; Simone, 2019). The protection given by the walls of the burrows allows the muscle to be exposed (Ansell \& Trueman, 1967; Seilacher, 1985), as observed in C. costata, where the anterior adductor muscle extends to the outer surface of the umbonal region, being pro- 
tected only by the protoplax and the thin pallial layer that builds it. Although it is known that there is a dependence of the substrate to support the shell (Rothschild, 2004), our study shows that $C$. costata has a strong and well-developed muscular system that moves its valves. That includes the well-developed pallial muscles located in posterior half of the mantle ventral edge (Fig. 2A: mb). As this pallial muscular bundle is transversely disposed, uniting edges of both valves, they can work as additional adductor muscles, helping in the valve's closure.

For Pholadidae, two stages in the life cycle are considered: the first is recognized as "active burrowing" and the second as "non-burrowing", thus having a stunted foot. Most pholadid species, if removed from the substrate, are unable to produce a new burrow (Ansell \& Nair, 1969; Ito, 2005). This information is supported by the features of the adult $C$. costata, which has a shortened foot despite a wide pedal aperture, suggesting the conclusion of the active burrowing stage. The $C$. costata foot is described herein as having a "superficial" origin because it lacks a strong root of muscles which is usually found in digging bivalves. This root includes mostly the four retractors, both protractors and sometimes integumentary muscles. They are not individualizable as usually found in other digging bivalves. As described above, the two pairs of foot retractors may be immersed in the integument, which is muscular, with fibers in the same direction of the retractor muscles. This is clearer in young specimens, becoming thinner in large ones. This can be interpreted as more sedentary way of life in adult phase, and more digger activities in young ones. Foot modification in the post-burrowing stage is seen in the pholadids Penitella penita (Conrad, 1837) and Aspidopholas obtecta (Sowerby, 1849), which the foot is stunted, and the visceral mass expanded, allowing more space for the development of the gonads (Evans, 1970; Wong, 1982). After the burrowing phase is over, $C$. costata does not build a callus (calcium accumulation in the anterior region between the valves), feature presented by other pholalids at the end of the burrowing stage (Turner, 1954).

The siphons are completely merged in C. costata, as well as in B. parva, B. candida, P. dactylus, P. loscombiana and Z. crispata. The periostracal layer is not attached to the siphon surface, which allows it to be trapped into the pallial sinus. Like in other pholadids, even when totally retracted, the siphon cannot be entirely trapped into the infrabranchial chamber. This feature is considered indicator of a burrowing habit into hard substrates (such as in Z. crispata), where the siphons suffer low or no abrasion (Purchon, 1955). Despite presenting large siphons, which cannot be entirely trapped, $C$. costata is inhabitant of soft substrates. Moreover, although showing substrate preference similar to $B$. candida, C. costata displays a substantially more robust siphon (Purchon, 1955), which is probably related to the great depth of the burrow of the species (Turner, 1954), which can reach almost 1 meter.

An extension at the posterior end of the visceral mass (Fig. 2B: fmv) probably is what Turner (1954) named as "collecting membrane", also present in Barnea (Purchon,
1955). This collects the excess sediment and deposits near the siphon to be expelled, which allows animals to feed at all times, even in muddy waters (Turner, 1954).

The well-developed ventricle in C. costata, already recorded for other pholadids (Purchon, 1955), may be associated with a long siphonal length, which requests hydraulic pressure to allow its extension in the surface. The amount of intestinal loops may suggest adaptation to poor nutritional food (Morton, 1983). The heart and kidney are located close to each other, as usually happen in mollusks and even other spiralian invertebrates (Giribet \& Edgecombe, 2020). The pericardium structures are located close to the stomach, as noted for other bivalves (Purchon, 1955; Morton, 1983; Simone et al., 2015), which certainly has some physiological justification.

The present study on detailed anatomy of a widespread species like $C$. costata certainly may be used as a comparative scenario for specimens from other regions of the species range. Possible differences can be found, indicating different species with similar shells. Additionally, the anatomical features of such valuable pholadid will represent the family in a wide phylogenetical approach which is being prepared, raising interesting discussion on the relationships of so aberrant bivalves.

\section{ACKNOWLEDGMENTS}

We thank the Conselho Nacional de Desenvolvimento Científico e Tecnológico (CNPq) for funding this study, C. Freire (Universidade Federal do Paraná) and reviewers for the advice and suggestions.

\section{AUTHORS' CONTRIBUTIONS}

N.S.: collect of samples, identification, dissection of part of samples, anatomical drawings, plastic arrangement of text and plates. L.R.L.S.: supervision, dissection of first part of samples, guidance of dissection and illustration steps, part of the descriptive text, anatomical photos, final revision of whole paper.

\section{REFERENCES}

Altena, C.O.V.R. 1968. The Holocene and recent marine bivalve Mollusca of Surinam. Studies on the Fauna of Suriname and other Guyanas, 10(1): 153-179.

Altena, C.O.V.R. 1971. The marine Mollusca of Suriname (Dutch Guiana) Holocene and recent Part II. Bivalvia and Scaphopoda. Zoologische Verhandelingen, Leiden,119(1): 1-100.

Ansell, A.D. \& Nair, N.B. 1969. A comparative study of bivalves which bore mainly by mechanical means. American Zoologist, 9(3 pt.2): 857-868.

Ansell, A.D. \& Trueman, E.R. 1967. Burrowing in Mercenaria mercenaria (L.) (Bivalvia, Veneridae). Journal of Experimental Biology, 46(1): 105-115.

Arias, A. \& Richter, A. 2012. Assessing the status of the endangered species Pholas dactylus (Bivalvia: Pholadidae) in the coast of Asturias. Revista de Investigación Marina, Biskaya, 19: 627-628. (XVII Iberian Symposium Marine Biology Studies) 
Bayle, E. 1880. Liste rectificative de quelques noms de genres et d'espèces. Journal de Conchyliologie, 28: 240-251.

Bieler, R. \& Mikkelsen, P.M. 2006. Bivalvia - a look at the Branches. Zoological Journal of the Linnean Society, 148: 223-235.

Bieler, R.; Mikkelsen, P.M. \& Giribet, G. 2013. Bivalvia - a discussion of known unknowns. American Malacological Bulletin, 31: 123-133.

Bin Ramli, M.F.S. \& Yusop, H.M. 2016. Identifying potential culture areas for angelwing clams (Pholas orientalis) in Malaysia. Journal of Agriculture and Veterinary Science, 9: 50-58.

Borzone, C.A.; Vargas, K.M.; Pezzuto, P.R. \& Tavares, Y.A.G. 2001. Aspectos da reprodução e dinâmica populacional de Chione pubera (Bory SaintVicent) (Bivalvia, Veneridae) no sul do Brasil. Revista Brasileira de Zoologia, 18(2): 333-349.

Conrad, T.A. 1869. Descriptions of new fossil Mollusca, principally Cretaceous. American Journal of Conchology, 5: 96-103.

Cullain, N.; Mciver, R.; Schmidt, A.L. \& Lotze, H.K. 2018. Spatial variation of macroinfaunal communities associated with Zostera marina beds across three biogeographic regions in Atlantic Canada. Estuaries and Coasts, 41(5): 1381-1396.

Dall, W.H. 1889. Notes on the Anatomy of Pholas (Barnea) costata Linne, and Zirphæa crispata Linne. Proceedings of the Academy of Natural Sciences of Philadelphia, 1889: 274-276.

Evans, J.W. 1970. Sexuality in the rock-boring clam Penitella penita (Conrad 1837). Canadian Journal of Zoology, 48(4): 625-627.

Fiori, S.M.; Simonetti, P. \& dos Santos, E.P. 2012. First record of Atlantic mud piddock, Barnea (Anchomasa) truncata (Bivalvia, Pholadidae) in Argentina. Aquatic Invasions, 7(2): 283-286.

Giribet, G. \& Edgecombe, G.D. 2020. The invertebrate tree of life. New Jersey, Princeton University Press.

Gomes-dos-Santos, A.; Lopes-Lima, M.; Castro, L.F.C. \& Froufe, E. 2019. Molluscan genomics: the road so far and the way forward. Hydrobiologia, 847(7): 1705-1726.

Grant, U.S. \& Gale, H.R. 1931. Catalogue of the marine Pliocene and Pleistocene Mollusca of California. Memoirs of the San Diego Society of Natural History, 1: 1-1036.

Haider, F.; Sokolov, E.P. \& Sokolova, I.M. 2018. Effects of mechanical disturbance and salinity stress on bioenergetics and burrowing behavior of the soft-shell clam Mya arenaria. Journal of Experimental Biology, 221: jeb172643.

Hoagland, K.E. 1983. Characters, character states, and taxa used in multivariate analysis of the Pholadacea. Tryonia, 8: 1-51.

Ito, Y. 2005. Functional shell morphology in early developmental stages of a boring bivalve Zirfaea subconstricta (Pholadidae). Paleontological Research, 9(2): 189-202.

Jeon, M.A.; Park, M.W.; Ku, K.; Ju, S.M.; Ko, P.; Kim, B.H.; Myeong, J.I. \& Lee, J.S. 2012. Gonadal development and reproductive cycle of the boring bivalve Barnea davidi (Deshayes, 1874) in Hampyeong Bay, Korea (Bivalvia: Pholadidae). Journal of Shellfish Research, 31(4): 951-958.

Kellogg, J.L. 1915. Ciliary Mechanisms of Lamellibranchs. Journal of Morphology, 26(4): 625-701.

Lamarck, J.B.P.A. 1818. Histoire Naturelle des Animaux sans Vertebres. Paris, De I'Imprimerie d'Abel Lanoe.

Lamarck, J.B.P.A. 1835. Histoire Naturelle des Animaux sans Vertebres. Paris, Imprimerie d'Hippolyte Tilliard.

Linnaeus, C. 1758. Systema Naturae per regna tria naturae, secundum classes, ordines, genera, species, cum characteribus, differentiis, synonymis, locis. Holmiae, Laurentius Salvius.

Monari, S. 2009. Phylogeny and biogeography of pholadid bivalve Barnea (Anchomasa) with considerations on the phylogeny of Pholadoidea. Acta Palaeontologica Polonica, 54(2): 315-335.
Moore, D.R. 1961. The Marine and Brackish Water Mollusca of the State of Mississippi. Gulf Research Report, 1: 1-58.

Morton, B. 1973. Some factors affecting the location of Arthritica crassiformis (Bivalvia: Leptonacea) commensal upon Anchomasa similis (Bivalvia: Pholadidae). Journal of Zoology, 170: 463-473.

Morton, B. 1983. Feeding and digestion in Bivalvia. In:Wilbur, K.M. (Ed.) The Mollusca. Physiology. New York, Academic Press. Part 2, p. 65-147.

Pacaud, J.M. 1998. Un nouveau genre de Pholadidae (Mollusca, Bivalvia) du Paléogène inférieur du nord de I'Atlantique. Apex, 13: 63-75.

Perry, L. \& Schwengel, J. 1956. Book Reviews: Marine Shells of the Western Coast of Florida. Bulletins of American Paleontology. Ithaca, Paleontologic Research Institution.

Pinn, E.H.; Richardson, C.A.; Thompson, R.C. \& Hawkins, S.J. 2005. Burrow morphology, biometry, age and growth of piddocks (Mollusca: Bivalvia: Pholadidae) on the south coast of England. Marine Biology, 147: 943-953.

Purchon, R. 1955. The structure and function of the British Pholadidae (rockboring Lamellibranchia). Proceedings of the Zoological Society of London, 124: 850-911.

Ribas, L.C.C. 2014. A Reserva Extrativista Marinha do Pirajubaé: sujeitos, memórias e saberes etnobiológicos. Instituto Federal de Santa Catarina, Florianópolis. (Publicação do IFSC)

Rios, E.C. 2009. Compendium of Brazilian sea shells. Porto Alegre, Evangraf.

Rothschild, S.B. 2004. Beachcomber's Guide to Gulf Coast Marine Life: Texas, Louisiana, Mississippi, Alabama, and Florida. 3.ed. Lanham, Taylor Trade Publishing. 179p.

Savazzi, E. 1987. Geometric and functional constraints on bivalve shell morphology. Lethaia, 20: 293-306.

Schepman, M.M. 1887. Bijdrage tot de kennis der mollusken-fauna van de schelpritsen van Suriname naar de door den Heer Voltz gemaakte verzameling bewerkt. Sammlungen des Geologischen Reichs-Museums in Leiden, 2: 150-168.

Seilacher, A. 1985. Bivalve morphology and function. University of Tennessee Studies in Geology, Suppl.13, 88-101.

Simone, L.R.L. 2019. Modifications in adductor muscles in bivalves. Malacopedia, 2: 1-12.

Simone, L.R.L.; Mikkelsen, P.M. \& Bieler, R. 2015. Comparative Anatomy of Selected Marine Bivalves from the Florida Keys, with Notes on Brazilian Congeners (Mollusca: Bivalvia). Malacologia, 58(1-1): 1-127.

Spencer, R.S. \& Campbell, L.D. 1987. The Fauna and Paleoecology of the Late Pleistocene Marine Sediments of Southeastern Virginia. Bulletins of American Paleontology, 92: 1-124.

Stasek, C.R. 1963. Synopsis and discussion of the association of ctenidia and labial palps in the bivalved molluscs. The Veliger, 6: 91-97.

Tryon, G. 1862. Order Pholadacea. Academy of Natural Sciences of Philadelphia, (1862): 65-93.

Turgeon, D.D. 1968. Guide to Estuarine and Inshore Bivalves of Virginia. (Master's Thesis). Williamsburg, College of William and Mary.

Turner, R.D. 1954. The family Pholadidae in the western Atlantic and the eastern Pacific I. Pholadinae. Johnsonia, 3: 1-64.

Turner, R.D. \& Santhakumaran, L.N. 1989. The genera Martesia and Lignopholas in the indo-pacific (Mollusca: Bivalvia: Pholadidae). Ophelia, 30: 155-186.

Velásquez, M. 2017. Marine boring bivalve mollusks from Isla Margarita, Venezuela. The Festivus, 49: 247-269.

Voight, J.R. \& Segonzac, M. 2012. At the bottom of the deep blue sea: a new wood-boring bivalve (Mollusca, Pholadidae, Xylophaga) from the Cape Verde Abyssal Plain (subtropical Atlantic). Zoosystema, 34: 171-180.

Wong, P.S. 1982. The morphology and population dynamics of Aspidopholas obtecta (Bivalvia: Pholadidae) boring into the Pacific oyster (Crassostrea gigas) in Hong Kong. Journal of Zoology, 198: 495-513. 